\title{
Life cycle assessment of energy generation in Poland
}

\author{
Lukasz Lelek $^{1}$ - Joanna Kulczycka ${ }^{2}$ • Anna Lewandowska ${ }^{3}$. Joanna Zarebska ${ }^{4}$
}

Received: 1 July 2014 / Accepted: 9 October 2015 / Published online: 3 November 2015

(C) The Author(s) 2015. This article is published with open access at Springerlink.com

\begin{abstract}
Purpose The paper presents, for the first time, a life cycle assessment (LCA) study of energy generation (i.e. electricity and heat production) in Poland. The aim is to determine and compare the potential impact of energy generation upon the environment in 2007, 2010 and 2012 based on countryspecific data bought from specialised government agencies. Methods LCA evaluations were made using the Impact2002+ method, which proposes a feasible implementation of a combined midpoint/damage approach. The method was chosen because it models risks and potential impacts per emission for several thousand chemicals, including greenhouse gas (GHG). The LCA method was used to monitor and assess the current energy system and introduced changes in energy structure at national level.

Results and discussion From the environmental perspective, the main problem of the Polish energy sector is that it is mainly based on fossil energy carriers, i.e. hard and brown coal (over $80 \%$ ). As the share of renewables in primary energy has increased from 6.7 to $10.2 \%$ (mainly biomass), a reduction in $\mathrm{SO}_{2}, \mathrm{NO}_{\mathrm{x}}$ and dust was noted in 2010 in comparison to
\end{abstract}

Responsible editor: Zbigniew Stanislaw Klos

Lukasz Lelek

lelek@meeri.pl

1 Mineral and Energy Economy Research Institute of the Polish Academy of Sciences, Wybickiego 7, 31-261 Krakow, Poland

2 Faculty of Management, AGH University of Science and Technology, Mickiewicza 30, 30-059 Krakow, Poland

3 Faculty of Commodity Science, Poznan University of Economics, Niepodleglosci 10, 61-875 Poznan, Poland

4 Faculty of Economics and Management, University of Zielona Gora, Podgorna 50, 65-246 Zielona Gora, Poland
2007. Unfortunately, acid and $\mathrm{CO}_{2}$ emissions increased significantly in 2012 as a result of higher consumption of brown coal as a fuel for energy production. The LCA study shows that the total environmental impact of the production and distribution of $1 \mathrm{TJ}$ of energy increased by about $4 \%$ in 2010 (compared to 2007) and by about $11 \%$ in 2012 (compared to 2010).

Conclusions Specific representative data of high quality can be delivered by agencies focused on energy issues and the national statistical office. They can help to considerably reduce the time and costs of life cycle inventory (LCI). These data, including a classification relating to electricity and heat generation and distribution in Poland, were converted to LCA results for the first time. It was noted that allocation between heat and power in the CHP system can be recognised as a source of uncertainty, and the results should be interpreted as sensitive to change in the allocation criteria.

Keywords Energy generation · Environmental impacts · Fossil fuels $\cdot$ LCA $\cdot$ LCI data $\cdot$ Poland

\section{Introduction}

Rational management of fossil fuels and reducing the impact of energy generation on the environment are major priorities of the EU energy policy. In Poland, the structure of energy generation is dominated (over $80 \%$ ) by the use of fossil energy carriers such as hard and brown coal and also by large power producers. In 2012, 35,667 MW of 37,720 MW installed capacity in the national electricity supply system came from large power plants (Table 1). In 2007-2012, the level of energy consumed had shown a slight upward trend but gross domestic product (GDP) grew faster than energy consumption (Fig. 1). An increase in the use of renewable energy, 
Table 1 The structure of generating capacity in the Polish National Electricity Supply System (MW) in 2007, 2010 and 2012

\begin{tabular}{llll}
\hline & 2007 & 2010 & 2012 \\
\hline Total & 35,096 & 37,367 & 37,720 \\
Power plants & 32,364 & 32,937 & 35,667 \\
Thermal power plants, including: & 30,155 & 30,716 & 30,750 \\
$\quad$ Hard coal & 20,580 & 20,152 & 20,129 \\
$\quad$ Brown coal & 8806 & 9630 & 9704 \\
$\quad$ Natural gas & 769 & 934 & 917 \\
Hydro power plants & 2209 & 2221 & 2311 \\
Industrial power plants & 2504 & 2486 & 2053 \\
Wind and other renewable & 229 & 1943 & 2606 \\
\hline
\end{tabular}

Source: Raport 2013, Raport 2011, Raport 2008

mostly energy from biomass (used for co-firing with coal) and wind, is also noticeable which is important for all sectors of the Polish economy as electricity and heat consumed have an impact on the environmental performance of other products from the life cycle perspective. The forecast changes in the structure of energy generation, mostly from nuclear and renewable sources, will lead to a reduction in environmental impact, i.e. emissions of $\mathrm{CO}_{2}$ will gradually decrease from approx. $328 \mathrm{mln} \mathrm{Mg}$ in 2007 to approx. $280 \mathrm{mln} \mathrm{Mg}$ in 2020 despite a growth in demand for final energy. It is planned that this demand will be supplied by nuclear plants (Polish Ministry of Economy 2009).

The growing demand for energy, the obligations arising from signing the Climate and Energy Package, and the still low efficiency of energy generation make producers take steps to modernise infrastructure, improve the eco-efficiency of energy production and construct new generation sources. It is important to introduce new solutions using ecologically friendly technology to improve the environmental impact of energy generation in Poland. One of the methods proposed to evaluate this is life cycle assessment (LCA). The use of LCA at the planning (ex ante), implementation (midterm) and evaluation of activities performed (ex post) stages makes it possible to indicate weak points as well as to allow us to indicate the ecological effects of planned investments in the energy system. The significance of the ecological burden of energy generation is relevant both for facilities powered by energy, e.g. buildings (Blengini and Carlo 2010; Optis and Wild 2010; Lewandowska et al. 2012), electrical and electronic equipment (Andrae and Andersen 2010; Hischier and Baudin 2010; Yung et al. 2009) or vehicles (Jaramillo et al. 2009; Lucas et al. 2012, Hawkins et al. 2013) as well as for all products and services. Due to the fact that consumption of energy is a significant element in the life cycles of products and differs depending on geographical conditions, the analysis of energy systems in individual countries is a basis for sustainable development. LCA has been used in several researches to evaluate energy generation at national, regional and local (Santoyo-Castelazo et al. 2011) level as well as for individual technological solutions (Lean and Smyth 2010; Atkins et al. 2010; Jaramillo et al. 2009; Nguyen and Hermansen 2012; Tonini and Astrup 2012). In 25 periodicals that have appeared in the last 18 years (1995-January 2013) and which contain papers relating to LCA on energy issues, a total of 108 relevant papers were found of which $93.5 \%$, as shown in Fig. 2, were published in the last 7 years (from 2005). There were only a few papers relating to Poland (Czaplicka-Kolarz et al. 2004; Bieda 2011; Lewandowska et al. 2013, Adamczyk and Dzikuć 2014) because in practice this method is still rarely used there (Kulczycka et al. 2011). Therefore, this paper presents the results of LCA studies in Poland to determine and compare the potential impact of energy generation upon the environment in 2007, 2010 and 2012. A brief review of the literature in the field of LCA of energy systems shows the research gaps in Poland in this field, which is important especially in the light of the Polish obligation to reduce greenhouse gas emissions. Therefore, it is necessary to take decisive action in order to help reduce emissions in particular sectors of the economy. The LCA method for the assessment of national energy systems could be a useful and universally applicable tool for the monitoring and assessment of proposed energy systems as it can indicate areas that have a significant impact on the environment (i.e. hot spots).
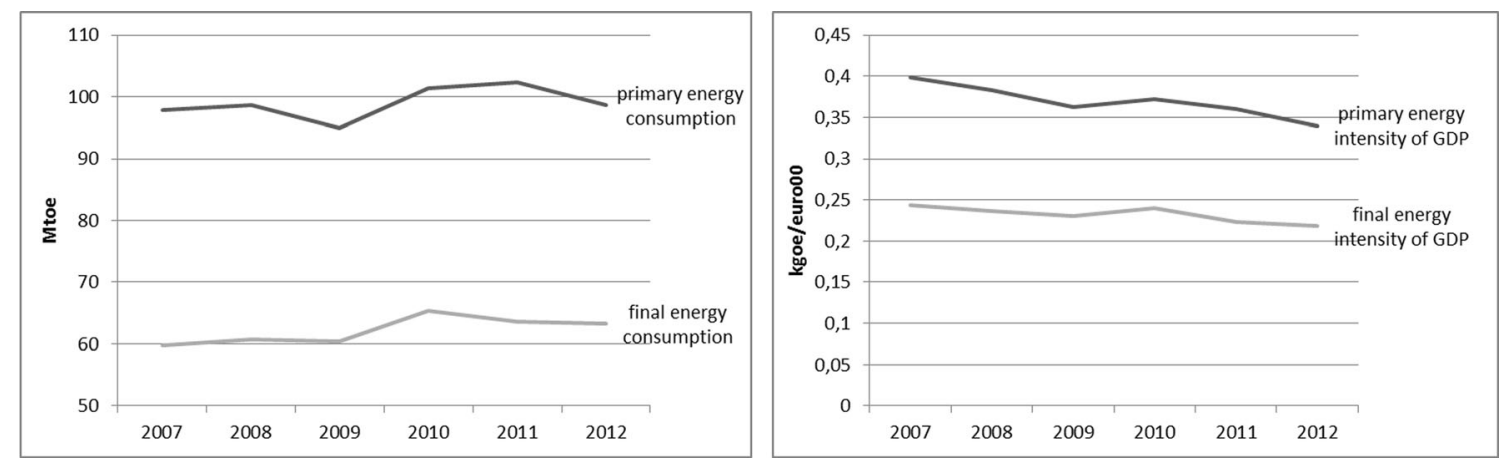

Fig. 1 Primary and final energy consumption, primary and final energy intensity of GDP in Poland, 2007-2012 


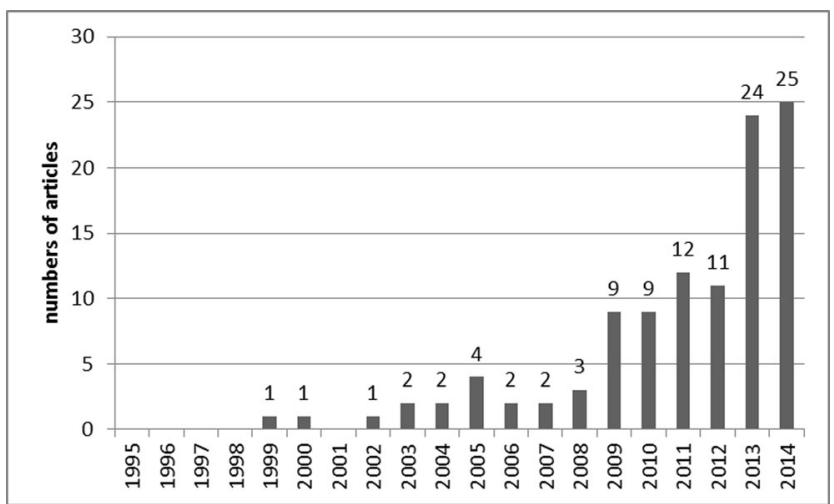

Fig. 2 Number of papers relating to LCA analyses for energy-related subjects found in 21 periodicals and published between 1995 and January 2013

\section{Methodology}

The LCA methodology used in this study follows the ISO 14040 and 14044 standards (ISO 14040 2009; ISO 14044 2009). LCA evaluations were made using the Impact2002+ method (Impact Assessment of Chemical Toxics), which proposes a feasible implementation of a combined midpoint/ damage approach with 14 midpoint categories and 4 damage categories (Lewandowska et al. 2015, Jolliet et al. 2003). The method was chosen because it models risks and potential impacts per emission for several thousand chemicals, including greenhouse gases (GHG). Impact2002+ highlights the impact of the system under analysis on global warming (midpoint) and climate change (damage), giving attention to GHG emissions from energy use (production and supply of electricity and heat). The other reasons are that Impact2002+ is representative for European conditions and it is a hybrid method combining midpoint and endpoint approaches which results in lower uncertainty. These data have become critical and necessary information relating to the power industry life cycle (Ou et al. 2011). Moreover, the final result of the analysis is an ecoindicator, giving a value for impact on the environment. This value is expressed in environmental points $(\mathrm{Pt})$.

\subsection{Goal and scope of the study}

The LCA study determines and compares the impact of the production and supply of electricity and heat to a final user upon the environment in the years 2007, 2010 and 2012, taking into account data concerning the excavation of raw materials, energy production (with the power plant infrastructure being excluded from the analysis, e.g. buildings, means of internal transport, equipment, only the transmission infrastructure and also the impact of the transmission grid being included) and energy distribution. The sensitivity analysis showed that the inclusion of infrastructure only increased the final results by about $1 \%$. The scope of the study covers all processes connected with energy production and the distribution of electricity (Fig. 3, Table 2). The energy production sector in Poland is mainly based on large power plants and CHP units. The most commonly used technology is based on thermal (steam) power plants, where the power unit consists of a steam boiler, steam turbine, synchronous generator and auxiliary equipment. The electricity is distributed via a transmission network (managed by a single operator) including power lines and 750-, 400- and 220-kV substations.

The functional unit is assumed to be the production and supply of 1 TJ of energy delivered to the final consumer. Inventory data specific to Poland were collected from:

- Energy agencies, i.e. the Energy Market Agency,

- The regulatory office, i.e. the Energy Regulatory Office,

- Input data bought from the Central Statistical Office (CSO) for the two sections: D: 35.1 - production, transmission, distribution and sale of electricity and 35.3- production and supply of steam, hot water and air to airconditioning systems. It covers the consumption of materials, emissions and the volume of waste and sewage generated related to the production and transmission of heat and electricity in the years 2007, 2010 and 2012 including elements of direct exchange with the environment and exchange between the product system and technosphere (Table 3). It is worth emphasising that the data consider the transmission infrastructure and disregard the infrastructure of the power plants themselves. The data are related to a synthesis of the overall energy, material and fuel balance of the whole energy system of the country, not for individual plants. They are classified in sections, divisions, groups according to the Polish Classification of Activities 2007 (PKD 2007) compiled on the basis of the Statistical Classification of Economic Activities in the European Community (NACE Rev. 2).

- Output data from both the CSO and Marshal's Offices-it is obligatory for industry to deliver data about impact on the environment (emissions, water, etc.). On the basis of this data, companies are obliged to pay fees and fines including payments for using the environment, service and concession fees, fees due under the Energy Law and the act on recycling of end-of-life vehicles, and for the purchase of Assigned Amount Units for greenhouse gas emissions, etc. This money provides the budget of The National Fund of Environmental Protection and Water Management (NFEPWM). The NFEPWM is the most significant environmental fund in Poland, and it is mainly used for the implementation of nationwide projects of strategic importance for the country (Kulczycka and Lelek 2014).

The production of energy in heat and power plants is a multi-output process in which two co-products can be 


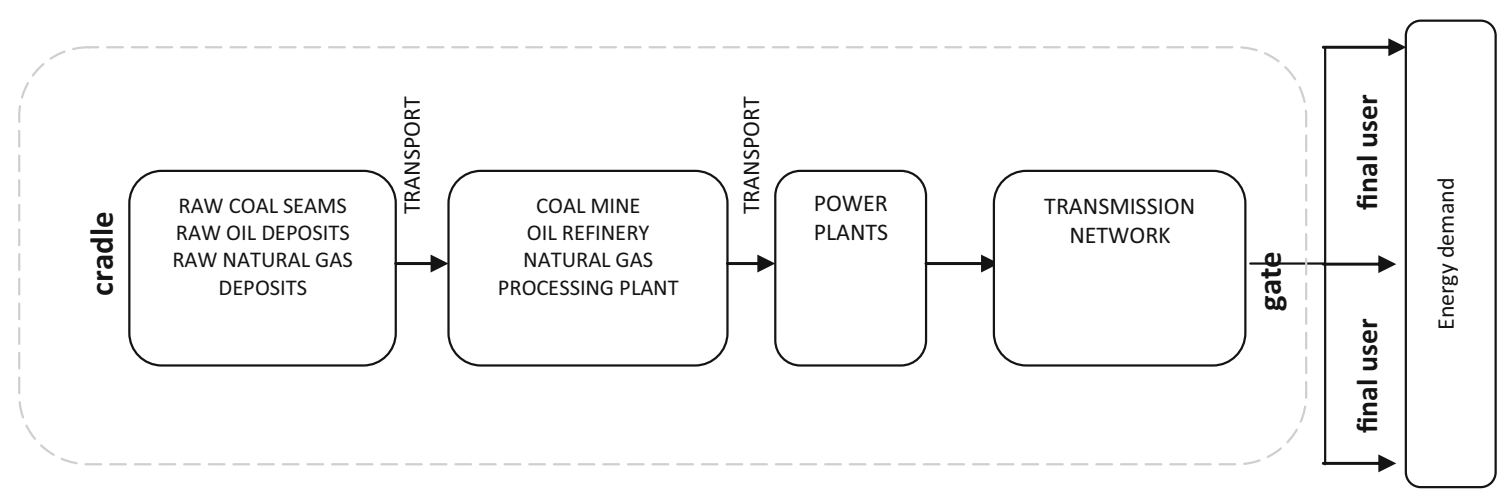

- - - - system boundary

Fig. 3 Scope of the LCA study (cradle to gate)

produced: heat and electricity. It results in a need to use the allocation procedure described by ISO 14044 (\# 4.3.4.2). The choice of an allocation method may play as important a role as the choice of an appropriate electricity supply mix. There have been long debates on the allocation method which is seen as a critical methodological issue. Choice of allocation method can have a considerable impact on the outcomes (range evet to $60 \%$ ) of an LCA, even for a system that is small, and where the allocation issue has been restricted to one process (Wardenaar et al. 2012). Therefore, in the case of a system which involves multi-output processes or recycling processes, allocation definitely is an important issue. Because of the use of aggregated data in this study, it was impossible to avoid allocation either by dividing up the unit process or by expanding the product system. Two ways of partitioning the inputs and outputs between two co-products are assumed: by reflecting the underlying physical relationships (using "a volume of production" as the allocation criterion) and by reflecting the economic value of the co-products (using "a price of heat and electricity valid for the years analysed" as the allocation criterion). The allocation factors obtained are presented in Table 4 . The production-related allocation factors are used as a default while the economic factors are used to perform the sensitivity analysis. The allocation factors obtained are presented in Table 4. Two main observations can be made based on the numbers presented in this table. The first one is the fact that a significant difference exists between the allocations obtained using two different kinds of allocation factor. If a production volume criterion is used, $75 \%$ of the environmental impact should be attributed to electricity and only $25 \%$ to heat. Very different allocation results are obtained using the economic (price) criterion. The prices of $1 \mathrm{TJ}$ of heat and $1 \mathrm{TJ}$ of electricity were similar, so the environmental impact should be divided between two co-products in a comparable way (approximately $50 \%$ for each co-product). From this point of view, the allocation can be recognised as a source of uncertainty and the results should be interpreted as sensitive to change in the allocation criterion. Fortunately, the relationship between the prices and the production volumes in all the years analysed was relatively constant, so the allocation results obtained in the frame of one allocation procedure can be regarded as comparable and stable. In the context of allocation, it is worth considering the use of exergy as an allocation criterion which is known as ELCA (exergy life cycle assessment) or $\mathrm{CExC}$ (cumulative exergy consumption). For this case study, all the data used have already been expressed in units of production, i.e. GWh (electricity), GJ (thermal energy), therefore, the calculation of exergy indicators for the production of electricity and heat for the whole energy system in Poland would require additional assumptions that ultimately contribute to greater uncertainty in the results. Therefore, in order to compare and verify the allocation factors for the system, two methods were calculated based on economic value and production volume.

\subsection{Reliability and representativeness of data sources}

The availability of data connected with national energy systems that are reliable and representative (as regards time, place and technology) is of paramount importance from the perspective of the quality of the results of an LCA study and forms the subject of numerous works (Cui et al. 2012; DominguezRamos et al. 2010; Harrison et al. 2010; Hondo 2005, Tan et al. 2010).

Producers holding concessions for energy production are obliged to deliver information to specific regulatory bodies; therefore, this data was collected for the entire group of plants (there are currently 19 commercial power stations and 50 CHPs in Poland) that jointly form the technological structure of energy production in Poland rather than from individual enterprises (operating within a specific time, territorial and technological framework). From the point of view of those carrying out LCA studies on the energy system, the ability to use statistical data is an opportunity to considerably reduce the time and costs of carrying out such analyses. The data for the life cycle inventory (LCI) does not have to be collected from individual power stations, CHPs and distribution companies as the methodology of collection of the information is 
standardised and invariable which makes the information reproducible and comparable. Even if, due to aggregation and the disregarding of certain areas (e.g. the infrastructure of a power plant), some uncertainty is incorporated into the analysis, this constraint affects the statistical data relating to each year to a similar extent.

For the LCA study, all the data gathered were converted into the form of an inventory table typical of LCA studies (Table 3) and calculations were based on a weighted average TJ. The data were verified for completeness by making a material and energy balance. The data may be deemed representative as regards territory and time as they originate from the place and time where and when the processes were operating (in Poland, all economic entities, including power plants and CHPs, are covered by an obligation to make reports to the office for statistics). The reports of the CSO relating to the production of energy do not consider infrastructure and, therefore, such information was not considered in the LCA case study presented. The reports are prepared on the basis of the following reporting documents:

- Monthly data on electricity generated

- A balance report on energy carriers

- A balance report on energy carriers and heat infrastructure

- A report on the basic activities of a commercial heat plant

- A report on the basic activities of a commercial hydro power plant

- A report on the power and production of hydro power plants and renewable energy sources

- A report on the consumption of fuels and energy

The quality of data was assessed by using the Pedigree Matrix and data quality indicators (DQI) according to the approach described in Canter et al. 2002 and Lewandowska et al. 2004. Data quality was evaluated using five criteria: reliability, completeness, temporal scope, geographical scope and technological scope. Some default requirements (ideal conditions) are assumed in the approach used, and these are called data quality goals (DQGs). The ideal conditions reflect the situation where the data used are verified and based on measurements (reliability), taken from an adequate sample of sites (completeness), over an adequate period (temporal scope), from an adequate area (geographical scope), from processes studied and company specific (technological scope). As the cells of the DQGs referred to the highest quality data, the highest values of DQIs are assigned to them which give a maximum value of DQI equal to 5 . Because the worst quality is described by a DQI equal to 1 , it is possible to obtain inventory points for quality levels which lie between 5.0 and 1.0, 
Table 3 The aggregated inventory data for production and transmission of $1 \mathrm{TJ}$ of energy (heat and electrical energy) in the years 2007,2010 and 2012

\begin{tabular}{|c|c|c|c|c|}
\hline Inventory element & Unit & 2007 & 2010 & 2012 \\
\hline \multicolumn{5}{|l|}{ Inputs } \\
\hline Sawn timber, chip and fibre wood boards & $\mathrm{m}^{3} / \mathrm{TJ}$ & 0.002 & 0.003 & 0.002 \\
\hline Soda, sodium hydroxide, sulfuric acid & $\mathrm{Mg} / \mathrm{TJ}$ & 0.015 & 0.010 & 0.012 \\
\hline Cement, lime & $\mathrm{Mg} / \mathrm{TJ}$ & 0.147 & 0.214 & 0.1525 \\
\hline Hot and cold rolled products & $\mathrm{Mg} / \mathrm{TJ}$ & 0.012 & 0.017 & 0.0285 \\
\hline Tin- and zinc-coated products & $\mathrm{Mg} / \mathrm{TJ}$ & 0.001 & 0.0007 & 0.001 \\
\hline Bare wires & $\mathrm{Mg} / \mathrm{TJ}$ & 0.0020 & 0.0019 & 0.0024 \\
\hline Hard coal & $\mathrm{Mg} / \mathrm{TJ}$ & 70.166 & 66.498 & 60.136 \\
\hline Brown coal & $\mathrm{Mg} / \mathrm{TJ}$ & 70.081 & 75.869 & 86.149 \\
\hline Natural gas (methane-rich, high nitrogen gas) & $\mathrm{TJ} / \mathrm{TJ}$ & 0.063 & 0.064 & 0.070 \\
\hline Light fuel oil & $\mathrm{Mg} / \mathrm{TJ}$ & 0.020 & 0.029 & 0.026 \\
\hline Heavy fuel oil & $\mathrm{Mg} / \mathrm{TJ}$ & 0.228 & 0.238 & 0.209 \\
\hline Coke gas & $\mathrm{TJ} / \mathrm{TJ}$ & 0.017 & 0.016 & 0.014 \\
\hline Furnace gas & $\mathrm{TJ} / \mathrm{TJ}$ & 0.012 & 0.011 & 0.012 \\
\hline Cooling system water & th $\mathrm{m}^{3} / \mathrm{TJ}$ & 11.0 & 10.5 & 9.5 \\
\hline Water for other technological purposes & th $\mathrm{m}^{3} / \mathrm{TJ}$ & 0.1 & 0.1 & 0.1 \\
\hline Water from own uptakes (surface and underground) & th $\mathrm{m}^{3} / \mathrm{TJ}$ & 11.1 & 10.6 & 9.6 \\
\hline \multicolumn{5}{|l|}{ Outputs } \\
\hline \multicolumn{5}{|l|}{ Emissions into the air } \\
\hline $\mathrm{SO}_{2}$ & $\mathrm{Mg} / \mathrm{TJ}$ & 0.901 & 0.514 & 0.496 \\
\hline $\mathrm{NO}_{\mathrm{x}}$ & $\mathrm{Mg} / \mathrm{TJ}$ & 0.335 & 0.324 & 0.294 \\
\hline $\mathrm{CO}$ & $\mathrm{Mg} / \mathrm{TJ}$ & 0.039 & 0.053 & 0.076 \\
\hline $\mathrm{CO}_{2}$ & $\mathrm{Mg} / \mathrm{TJ}$ & 201.891 & 201.884 & 214.063 \\
\hline Dust contamination & $\mathrm{Mg} / \mathrm{TJ}$ & 0.049 & 0.029 & 0.036 \\
\hline Heavy metals & $\mathrm{kg} / \mathrm{TJ}$ & 0.089 & 0.182 & 0.102 \\
\hline \multicolumn{5}{|l|}{ Sewage } \\
\hline Treated & th $\mathrm{m}^{3} / \mathrm{TJ}$ & 0.2 & 0.3 & 0.1 \\
\hline Untreated & th $\mathrm{m}^{3} / \mathrm{TJ}$ & 9.6 & 8.6 & 9.1 \\
\hline Into surface waters & th $\mathrm{m}^{3} / \mathrm{TJ}$ & 9.8 & 8.8 & 9.2 \\
\hline \multicolumn{5}{|l|}{ Waste } \\
\hline Slag, furnace ash and boiler dusts & $\mathrm{Gg} / \mathrm{TJ}$ & 0.0033 & 0.0023 & 0.0032 \\
\hline Fly ash from coal/fly ash from co-combustion & $\mathrm{Gg} / \mathrm{TJ}$ & 0.0178 & 0.0063 & 0.0063 \\
\hline Ash and slag mixtures from wet furnace waste disposal & $\mathrm{Gg} / \mathrm{TJ}$ & No data & 0.0108 & 0.0143 \\
\hline Fly ash and solid waste mixtures from lime methods of exhaust gas desulfurization & $\mathrm{Gg} / \mathrm{TJ}$ & No data & 0.0049 & 0.0052 \\
\hline
\end{tabular}

Source: data bought from Central Statistical Office, Environment 2013; Kulczycka and Pietrzyk-Sokulska 2012

in steps of 0.2. As a next step, the DQI values are linked to the parameters of the probability distribution (in our study, the triangle distribution is used). The values of maximum and minimum are calculated based on the mean deviation (\%). The lower the DQI, the higher is the deviation assumed. For the highest quality data $(\mathrm{DQI}=5.0)$, the assumed mean deviation is only $10.0 \%$ while for the lowest quality data $(\mathrm{DQI}=1.0)$ the assumed mean deviation is $50.0 \%$. After calculating the values of minimum and maximum for each inventory point, uncertainty analysis was performed using
Monte Carlo simulations (1000 runs). The quality of inventory data gathered in our study was assessed as between $\mathrm{DQI}=4.6$ and 4.0 which indicates a high quality of the data. The emission data was assessed as higher quality with lower mean deviation $(14 \%)$ while the activity data was assessed as $\mathrm{DQI}=4.0$ (mean deviation equalled $20 \%$ ). It was assumed that information about emissions originated from the power plants' own measurements. Activity data are potentially more affected by estimations and simplifications, so the final quality is a bit lower. The maximal level of quality was 
Table 4 The physical and economic allocation factors used in the study for partition of the inputs and outputs between two co-products: a heat and an electricity

\begin{tabular}{|c|c|c|c|c|c|c|}
\hline \multirow[t]{2}{*}{ Co-products } & \multicolumn{3}{|c|}{ Volume of production (TJ/year) } & \multicolumn{3}{|c|}{ Physical allocation factors (\%) } \\
\hline & 2007 & 2010 & 2012 & 2007 & 2010 & 2012 \\
\hline Heat & 172,848 & 187,242 & 172,626 & 24.2 & 26.0 & 24.4 \\
\hline Electricity & 542,401 & 531,706 & 535,100 & 75.8 & 74.0 & 75.6 \\
\hline Total & 715,249 & 718,948 & 707,726 & 100.0 & 100.0 & 100.0 \\
\hline \multirow[t]{2}{*}{ Co-products } & \multicolumn{3}{|c|}{ Price (PLN/TJ) } & \multicolumn{3}{|c|}{ Economic allocation factors $(\%)$} \\
\hline & 2007 & 2010 & 2012 & 2007 & 2010 & 2012 \\
\hline Heat & 35,000 & 43,000 & 47,720 & 49.5 & 44.2 & 46.0 \\
\hline Electricity & 35,778 & 54,256 & 55,933 & 50.5 & 55.8 & 54.0 \\
\hline Total & 70,778 & 97,256 & 103,653 & 100.0 & 100.0 & 100.0 \\
\hline
\end{tabular}

Source: Buńczyk 2013; The Energy Market Agency 2013; Informacja 2008; Informacja 2011; Informacja 2013; Łuba et al. 2012 identified for the following four criteria: temporal scope, geographical scope, technological scope and completeness. A lower quality was assessed in relation to the criterion of "reliability". The initial data originated from all conventional power plants included in the electricity system in Poland and was gathered by the National Statistical Office of Poland. For this reason, we assumed that, from the geographical and technological perspective, the data is of high quality. This data was aggregated, which resulted in the application of some estimates and simplifying assumptions. The secondary data were derived from the Ecoinvent $\mathrm{v} 2.2$ database and were supplied by the quality information gathered by data providers.
The results of the uncertainty analysis are presented in section 3 (Table 6), as values of the standard deviation associated with the results of the environmental indicators.

Moreover, data were compared to the Ecoinvent database. In a recent version of the Ecoinvent v. 2.2 database, one may find inventory data relating to the production of electricity in 29 countries which take into account the quality structure of the production (per percentage share of individual energy carriers) and the distribution of energy generated to final users. Ecoinvent v. 2.2 also includes data for Poland which are deemed representative for 1992-2004. However, the energy sector is characterised by rapid change, including reducing

Table 5 The structure of electrical energy production in Poland as per carriers in selected years

\begin{tabular}{|c|c|c|c|c|c|c|c|c|}
\hline Year/energy carriers & $\begin{array}{l}\text { Ecoinvent V2.2 } \\
\%\end{array}$ & $\begin{array}{l}2006 \\
\%\end{array}$ & $\begin{array}{l}2010 \\
\%\end{array}$ & $\begin{array}{l}2012 \\
\%\end{array}$ & $\begin{array}{l}2015 \\
\%\end{array}$ & $\begin{array}{l}2020 \\
\%\end{array}$ & $\begin{array}{l}2025 \\
\%\end{array}$ & $\begin{array}{l}2030 \\
\%\end{array}$ \\
\hline Hard coal & 55.4 & 58.3 & 53.0 & 49.6 & 44.9 & 40.2 & 32.4 & 35.6 \\
\hline Brown coal & 36.3 & 33.8 & 34.7 & 33.3 & 36.5 & 25.6 & 26.8 & 21.0 \\
\hline Natural gas & 3.3 & 3.1 & 3.4 & 3.9 & 3.6 & 5.4 & 6.3 & 6.6 \\
\hline Petroleum products & 1.6 & 1.1 & 1.5 & 1.8 & 1.8 & 1.8 & 1.6 & 1.5 \\
\hline Nuclear energy & 0.0 & 0.0 & 0.0 & 0.0 & 0.0 & 6.7 & 11.7 & 15.7 \\
\hline Renewable energy & 2.1 & 2.6 & 6.2 & 10.4 & 12.1 & 19.3 & 20.2 & 18.8 \\
\hline Water & 1.5 & 0.7 & 0.9 & 1.3 & 1.0 & 1.0 & 0.9 & 0.8 \\
\hline Wind & 0.1 & 0.1 & 0.7 & 2.9 & 2.6 & 4.4 & 5.0 & 4.6 \\
\hline Biomass & 0.5 & 1.7 & 4.0 & 5.4 & 6.5 & 10.1 & 9.3 & 8.5 \\
\hline Biogas & 0.1 & 0.2 & 0.6 & 0.8 & 2.0 & 3.7 & 5.1 & 4.9 \\
\hline Solar & 0.0 & 0.0 & 0.0 & 0.0 & 0.0 & 0.0 & 0.0 & 0.0 \\
\hline Water pumping stations & 1.1 & 0.7 & 0.8 & 0.3 & 0.7 & 0.6 & 0.6 & 0.5 \\
\hline Waste & 0.0 & 0.4 & 0.5 & 0.6 & 0.4 & 0.4 & 0.4 & 0.3 \\
\hline Total & 100.0 & 100.0 & 100.0 & 100.0 & 100.0 & 100.0 & 100.0 & 100.0 \\
\hline
\end{tabular}

Source: Energy Policy (2009) 
the impact on the environment, e.g. through increased use of renewable energy sources. Therefore, such data may be considered as requiring some verification through reference to more recent statistics (Henriksson et al. 2015, Table 5).

If we compare data relating to the structure of electricity production in Poland broken down by energy carrier, as contained in Ecoinvent $\mathrm{v} 2.2$, to the forecast values for the remaining years, we may observe that the differences are considerable, especially for 2012. The Ecoinvent data are similar to the statistics for 2006 and 2010 which means that the time representativeness provided for such data (1992-2004) is justifiable, and the data may be used as a reliable source of inventory data for processes carried out even as late as 2010 . However, an analysis of analogous statistics from 2010 shows that the data should be adjusted to take account of the following trends: a decrease in the share of hard and brown coal, an increase in the share of natural gas and an increase in the share of biomass, biogas and wind energy.

\section{$3 \mathrm{LCA}$ results}

The production and distribution of $1 \mathrm{TJ}$ of energy in Poland in 2007 led to a negative impact equalling $63.2 \mathrm{Pt}$, whereas carrying out the same function in 2010 led to an impact higher by $4 \%$ and amounting to $65.7 \mathrm{Pt}$ and in 2012 to an impact equalling $74.1 \mathrm{Pt}$ (an $11.3 \%$ increase compared to 2010) (Fig. 4, Table 6).

As regards quality, the structure of the impact upon the environment is similar for both years and dominated by four impact categories (Table 6, Fig. 5): global warming (21.9 Pt for 2007, 22.1 Pt for 2010, 23.06 Pt for 2012), non-renewable energy (18.6 Pt for 2007, 19.6 Pt for 2010, 17.76 Pt for 2012), respiratory disorder resulting from emission of inorganic compounds (13.07 Pt for 2007, 9.90 Pt for $2010,9.16 \mathrm{Pt}$ for 2012) and terrestrial ecotoxicity (7.79 Pt for 2007, 11.87 Pt for 2010, 20.89 Pt for 2012). In all three cases, the total impact within those four impact categories (from among 14) constitutes more than $95 \%$ of the total value of the Ecoindicator. As regards the four dominant impact categories, respiratory inorganics showed a decrease of impact in 2010 as compared to 2007. The impact decreased by $3.17 \mathrm{Pt}$, which constitutes a reduction of $24 \%$. In the three other cases, the production of $1 \mathrm{TJ}$ of energy was less favourable for the environment in 2010 than 3 years earlier. The comparison between the situations in 2010 and 2012 shows that not only was a lower indicator value obtained for respiratory inorganics, but also for non-renewable energy (decreased by $0.74 \mathrm{Pt}$ for respiratory and $1.81 \mathrm{Pt}$ for non-renewable energy).

Table 7 shows the four dominant impact categories characterised with respect to the occurrence of environmental aspects (distinguishing between direct and indirect impacts).

In order to obtain the results presented in Table 7, the ISO 14001's concept of "direct" and "indirect" environmental aspects can be used. The main motivation for doing that was to identify the stages in the life cycles analysed which are mostly responsible for generating the impact in four impact categories: respiratory inorganics, terrestrial ecotoxicity, global warming and non-renewable energy. Two unit processes-production of energy in power plants and transmission of the energy via the transmission grid-have been treated as foreground processes. The inventory tables for these two processes contained two sorts of data: elementary flows and activity data (exchange with the technosphere). All elementary flows included in these inventory tables have been treated as direct environmental aspects because one can assume that the power plant has direct management control over the emissions emitted by its own plant.
Fig. 4 Results of the endpoints indicator for production and distribution of $1 \mathrm{TJ}$ of energy in Poland $(P L)$ in the years 2007 , 2010 and $2012(\mathrm{Pt})$

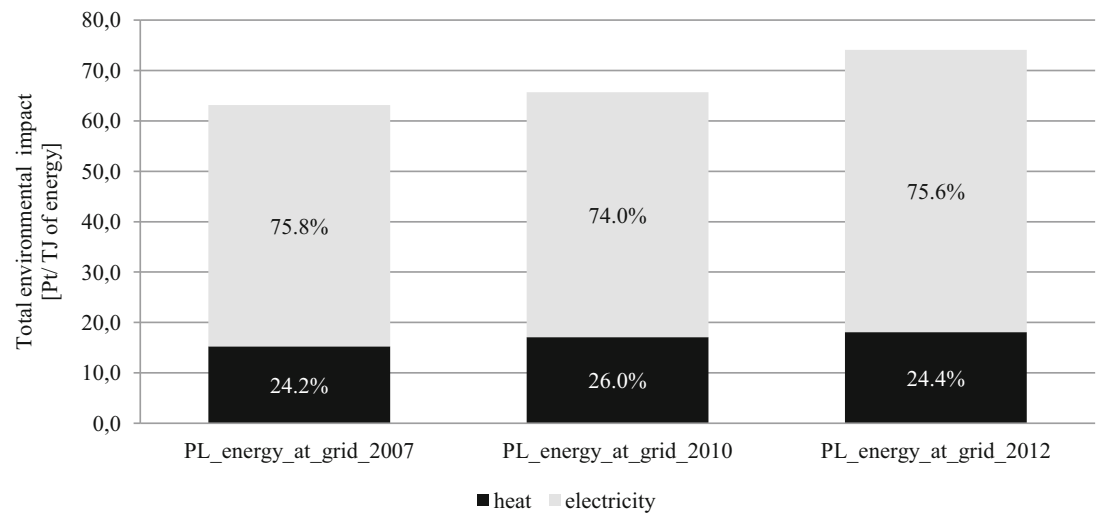




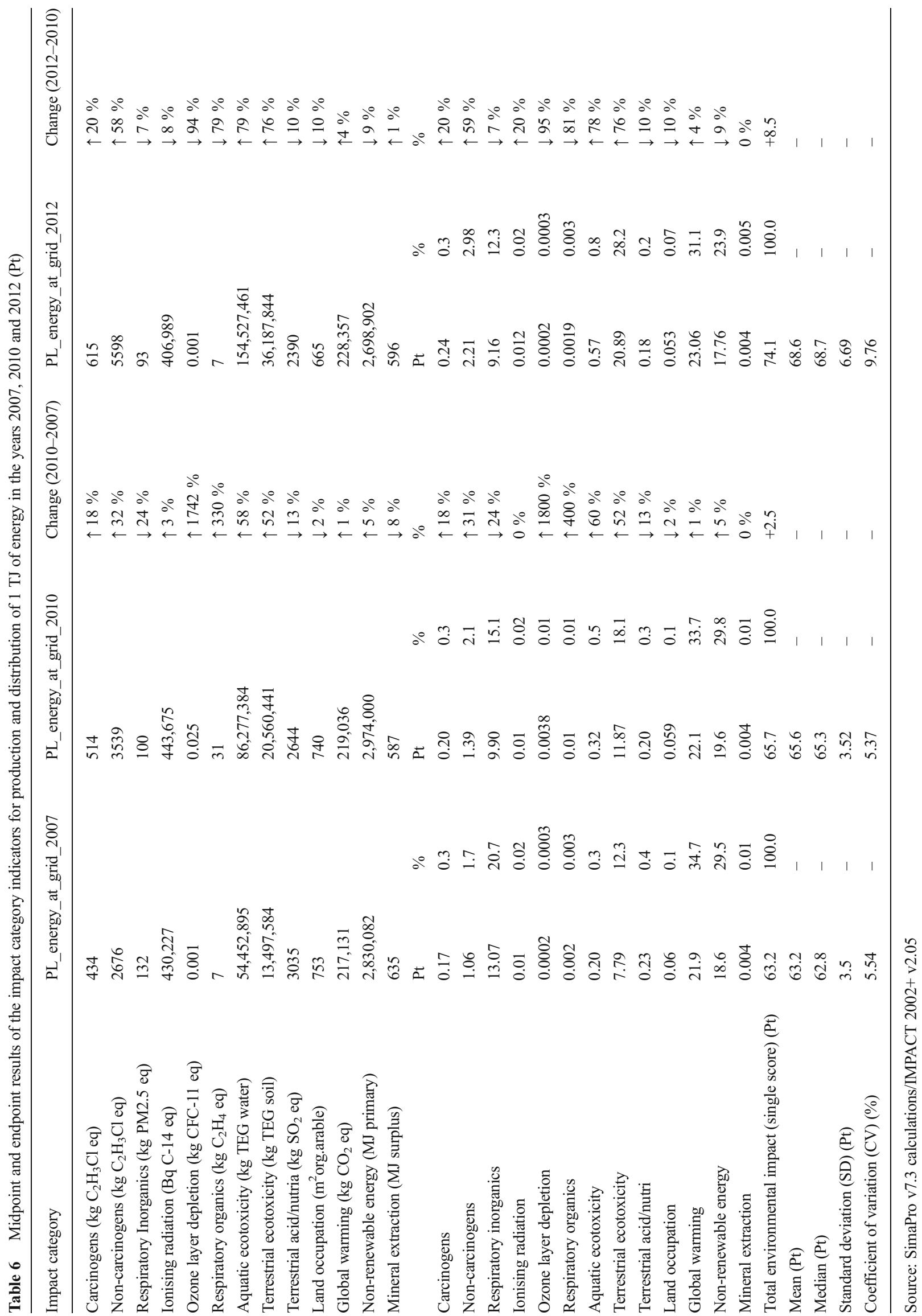


The case of respiratory inorganics for the year 2007 can be used as an example. The indicator result for this impact category is equal to $13.1 \mathrm{Pt}$ per $1 \mathrm{TJ}$ of energy, of which $55 \%$ of the impact is the result of emissions of $\mathrm{SO}_{2}$ into the air, $35.5 \%$ of $\mathrm{NO}_{\mathrm{x}}$ and $9.1 \%$ of dust. This indicator result provides $20.7 \%$ of the total score. This indicates that respiratory inorganics are an important issue. In the entire product system, it has been calculated that the emission of $\mathrm{SO}_{2}$ (in 2612 unit processes) equals $0.934 \mathrm{Mg}$ of which $96.5 \%$ is emitted directly by the power plant and is treated in our analysis as a direct environmental aspect. In total, $3.5 \%(0.033 \mathrm{Mg})$ was emitted by suppliers - mainly in mines and during sewage treatment processes and which were therefore classified as indirect environmental aspects. As one can see, the main sources of inorganic and GHG emissions are in the foreground processes while the remaining parts of the product system analysed play a marginal role. By contrast, the impacts from the impact of terrestrial ecotoxicity and non-renewable energy were classified as indirect environmental aspects because they were generated outside the power plants and transmission network. In the case of the scenario for 2007, the total impact in this category is $7.8 \mathrm{Pt}$, of which $71.3 \%$ is related to the emission of $\mathrm{Al}$ and $16.7 \%$ to the emission of $\mathrm{Zn}$. These emissions mainly take place during sewage treatment processes and the production of waste fuel.

\section{Discussion of the results}

In accordance with the results obtained, the production and distribution of $1 \mathrm{TJ}$ of energy was connected with the total emission (from the entire product system) of:

- $\quad 0.934 \mathrm{Mg} \mathrm{SO}_{2}, 0.368 \mathrm{Mg} \mathrm{NO}_{\mathrm{x}}, 0.106 \mathrm{Mg}$ particulates in 2007

- $\quad 0.544 \mathrm{Mg}$ of $\mathrm{SO}_{2}, 0.367 \mathrm{Mg}$ of $\mathrm{NO}_{\mathrm{x}}, 0.083 \mathrm{Mg}$ particulates in 2010

Fig. 5 Results of the impact category indicators for the production and distribution of $1 \mathrm{TJ}$ of energy in the years 2007 , 2010 and $2012(\mathrm{Pt})$
- $\quad 0.616 \mathrm{Mg}$ of $\mathrm{SO}_{2}, 0.327 \mathrm{Mg}$ of $\mathrm{NO}_{\mathrm{x}}, 0.096 \mathrm{Mg}$ particulates in 2012

Reductions in these emissions are mainly related to an increasing share of RES including biomass. However, the use of biomass on a large scale faces a number of barriers which are mainly related to the supply of raw material. The share of agricultural biomass in overall biomass consumption should increase, and forest biomass should reduce as a result of the Regulation of the Minister of Economy of 18 October 2012 (Journal of Laws of 2012. Pos. 1229). However, due to the low market potential compared to the demand for agricultural biomass and also cultural barriers related to their use in power plants, they are faced with a problem in obtaining raw material. They are forced to import biomass from different regions of the country or make imports from abroad resulting in a limitation in the development of the domestic market. In 2012, energy from biomass co-firing and from wind turbines had the highest share in RES (Fig. 6).

The higher share of brown coal in the structure of energy production in 2010-2012 resulted in a small increase in emissions. The higher use of brown coal was a result of the consolidation process involving the largest energy company in Poland (Polish Energy Group) and the largest open pit brown coal mines (KWB Belchatow, KWB Turow).

Growth of 13.1 Pt in 2007-2012 was seen in the terrestrial ecotoxicity category, and this was associated with indirect impact mainly associated with the use of hot and cold rolled products, including iron, aluminium and cables, which resulted in higher emissions of heavy metals into the soil.

Power plants and CHPs using brown and hard coal contribute to the development of global warming. Total

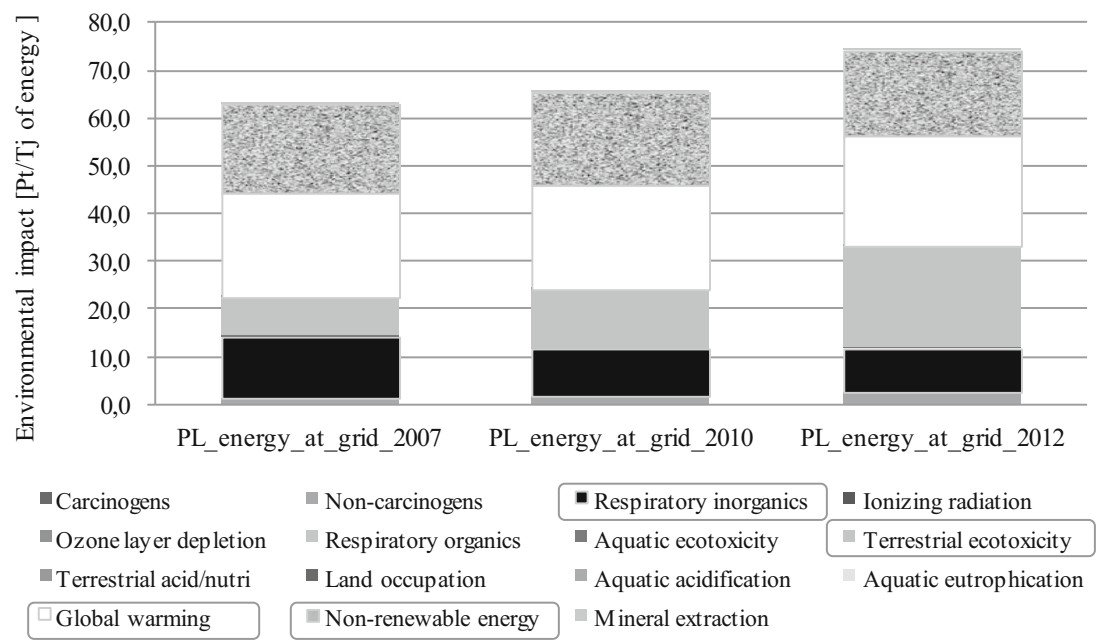


Table 7 Sources of elementary flows for four dominant impact categories in relation to production and distribution of 1 TJ of energy in Poland (PL) in 2007, 2010 and 2012

\begin{tabular}{|c|c|c|c|}
\hline Scenario & $\begin{array}{l}\text { Elementary flows and their } \\
\text { share in impact category } \\
\text { indicator result-per entire } \\
\text { product system }\end{array}$ & $\begin{array}{l}\text { Elementary flows as direct } \\
\text { environmental aspects in } \\
\text { power plants and transmission } \\
\text { infrastructure }\end{array}$ & $\begin{array}{l}\text { Elementary flows as indirect } \\
\text { environmental aspects in } \\
\text { remaining processes }\end{array}$ \\
\hline \multirow[t]{13}{*}{ PL_energy_at_grid_2007 } & \multicolumn{3}{|l|}{ Respiratory inorganics $=13.1 \mathrm{Pt}(20.7 \%) / 1 \mathrm{TJ}$ of energy } \\
\hline & Emissions to air: $\mathrm{SO}_{2}(55 \% / 0.934 \mathrm{Mg})$ & $96.5 \%$ & $3.5 \%$ (coal mines and sewage treatment) \\
\hline & Emissions to air: $\mathrm{NO}_{\mathrm{x}}(35.5 \% / 0.368 \mathrm{Mg})$ & $90.8 \%$ & $9.2 \%$ (coal mines and sewage treatment) \\
\hline & Emissions to air: particulates $(9.1 \% / 0.106 \mathrm{Mg})$ & $46.4 \%$ & $53.6 \%$ (coal mines and sewage treatment) \\
\hline & \multicolumn{3}{|l|}{ Terrestrial ecotoxicity $=7.8 \mathrm{Pt}(12.3 \%) / 1 \mathrm{TJ}$ of energy } \\
\hline & Emissions to soil: aluminium $(71.3 \% / 0.013 \mathrm{Mg})$ & $0.0 \%$ & $\begin{array}{l}100.0 \% \text { (digested matter production and } \\
\text { sewage treatment) }\end{array}$ \\
\hline & Emissions to soil: copper $(7.14 \% / 0.00014 \mathrm{Mg})$ & $0.0 \%$ & $100.0 \%$ (sewage treatment) \\
\hline & Emissions to soil: zinc $(16.7 \% / 0.00038 \mathrm{Mg})$ & $0.0 \%$ & $100.0 \%$ (sewage treatment) \\
\hline & \multicolumn{3}{|l|}{ Global warming $=21.9 \mathrm{Pt}(34.7 \%) / 1 \mathrm{TJ}$ of energy } \\
\hline & Emissions to air: $\mathrm{CO}_{2}(97.83 \% / 214.504 \mathrm{Mg})$ & $95.1 \%$ & $\begin{array}{l}4.9 \% \text { (coal mines. natural gas burning and } \\
\text { sewage treatment) }\end{array}$ \\
\hline & \multicolumn{3}{|l|}{ Non-renewable energy $=18.6 \mathrm{Pt}(29.5 \%) / 1 \mathrm{TJ}$ of energy } \\
\hline & Raw material: coal hard. in ground $(66.2 \% / 98.095 \mathrm{Mg})$ & $0.0 \%$ & $100.0 \%$ (hard coal mine) \\
\hline & Raw material: coal brown. in ground $(27.3 \% / 78.028 \mathrm{Mg})$ & $0.0 \%$ & $100.0 \%$ (brown coal mine) \\
\hline \multirow[t]{13}{*}{ PL_energy_at_grid_2010 } & \multicolumn{3}{|l|}{ Respiratory inorganics $=9.9 \mathrm{Pt}(15.1 \%) / 1 \mathrm{TJ}$ of energy } \\
\hline & Emissions to air: $\mathrm{SO}_{2}(42.4 \% / 0.544 \mathrm{Mg})$ & $94.5 \%$ & $5.5 \%$ (coal mines and sewage treatment) \\
\hline & Emissions to air: $\mathrm{NO}_{\mathrm{x}}(46.5 \% / 0.367 \mathrm{Mg})$ & $88.3 \%$ & $11.7 \%$ (coal mines and sewage treatment) \\
\hline & Emissions to air: particulates $(8.69 \% / 0.083 \mathrm{Mg})$ & $35.0 \%$ & $65.0 \%$ (coal mines and sewage treatment) \\
\hline & \multicolumn{3}{|l|}{ Terrestrial ecotoxicity=11.9 Pt $(18.1 \%) / 1 \mathrm{TJ}$ of energy } \\
\hline & Emissions to soil: aluminium $(80.2 \% / 0.022 \mathrm{Mg})$ & $0.0 \%$ & $\begin{array}{l}100.0 \% \text { (digested matter production and } \\
\text { sewage treatment) }\end{array}$ \\
\hline & Emissions to soil: copper $(4.74 \% / 0.00014 \mathrm{Mg})$ & $0.0 \%$ & $100.0 \%$ (sewage treatment) \\
\hline & Emissions to soil: zinc $(11.5 \% / 0.00034 \mathrm{Mg})$ & $0.0 \%$ & $100.0 \%$ (sewage treatment) \\
\hline & \multicolumn{3}{|l|}{ Global warming $=22.1 \mathrm{Pt}(33.7 \%) / 1 \mathrm{TJ}$ of energy } \\
\hline & Emissions to air: $\mathrm{CO}_{2}(97.85 \% / 216.259 \mathrm{Mg})$ & $93.4 \%$ & $\begin{array}{l}6.6 \% \text { (coal mines. natural gas burning and } \\
\text { sewage treatment) }\end{array}$ \\
\hline & \multicolumn{3}{|l|}{ Non-renewable energy $=19.6 \mathrm{Pt}(29.8 \%) / 1 \mathrm{TJ}$ of energy } \\
\hline & Raw material: coal hard. in ground $(59.7 \% / 93.082 \mathrm{Mg})$ & $0.0 \%$ & $100.0 \%$ (hard coal mine) \\
\hline & Raw material: coal brown. in ground $(25.6 \% / 77.107 \mathrm{Mg})$ & $0.0 \%$ & $100.0 \%$ (brown coal mine) \\
\hline \multirow[t]{13}{*}{ PL_energy_at_grid_2012 } & \multicolumn{3}{|l|}{ Respiratory inorganics $=9.16 \mathrm{Pt}(12.3 \%) / 1 \mathrm{TJ}$ of energy } \\
\hline & Emissions to air: $\mathrm{SO}_{2}(44.28 \% / 0.616 \mathrm{Mg})$ & $94.2 \%$ & $5.8 \%$ (coal mines and sewage treatment) \\
\hline & Emissions to air: $\mathrm{NO}_{\mathrm{x}}(44.64 \% / 0.327 \mathrm{Mg})$ & $90.2 \%$ & $9.8 \%$ (coal mines and sewage treatment) \\
\hline & Emissions to air: particulates $(10.36 \% / 0.096 \mathrm{Mg})$ & $37.7 \%$ & $62.3 \%$ (coal mines and sewage treatment) \\
\hline & \multicolumn{3}{|l|}{ Terrestrial ecotoxicity=20.9 (28.2\%) Pt/1 TJ of energy } \\
\hline & Emissions to soil: aluminium $(86.36 \% / 0.041 \mathrm{Mg})$ & $0.0 \%$ & $\begin{array}{l}100.0 \% \text { (digested matter production and } \\
\text { sewage treatment) }\end{array}$ \\
\hline & Emissions to soil: copper $(3.37 \% / 0.00018 \mathrm{Mg})$ & $0.0 \%$ & $100.0 \%$ (sewage treatment) \\
\hline & Emissions to soil: zinc $(8.23 \% / 0.0005 \mathrm{Mg})$ & $0.0 \%$ & $100.0 \%$ (sewage treatment) \\
\hline & \multicolumn{3}{|l|}{ Global warming $=23.1 \mathrm{Pt}(31.1 \%) / 1 \mathrm{TJ}$ of energy } \\
\hline & Emissions to air: $\mathrm{CO}_{2}(97.25 \% / 226.115 \mathrm{Mg})$ & $93.3 \%$ & $\begin{array}{l}6.7 \% \text { (coal mines. natural gas burning and } \\
\text { sewage treatment) }\end{array}$ \\
\hline & \multicolumn{3}{|l|}{ Non-renewable energy $=17.8 \mathrm{Pt}(23.9 \%) / 1 \mathrm{TJ}$ of energy } \\
\hline & Raw material: coal hard. in ground $(59.6 \% / 84.15 \mathrm{Mg})$ & $0.0 \%$ & $100.0 \%$ (hard coal mine) \\
\hline & Raw material: coal brown. in ground $(32.0 \% / 87.307 \mathrm{Mg})$ & $0.0 \%$ & $100.0 \%$ (brown coal mine) \\
\hline
\end{tabular}

Source: own calculations based on SimaPro v7.3/ IMPACT 2002+ v2.05

GHG emissions for the production phase alone have not changed in 2007 and 2010, while they increased in
2012 mainly due to use of larger amounts of brown coal and natural gas. 
Fig. 6 Production of electricity (MWh) for individual RES technologies in 2007-2012

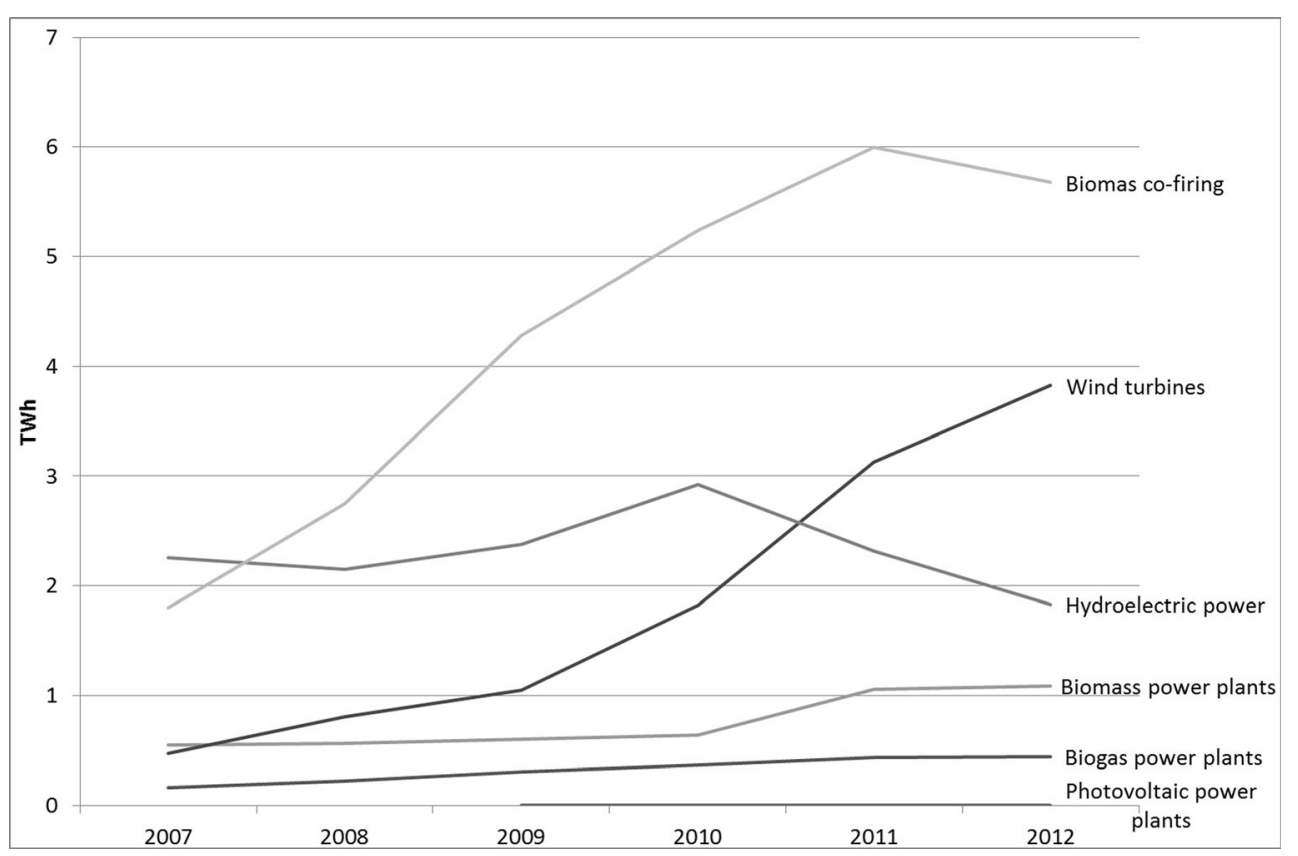

\section{Conclusions}

The need to attain a $20 \%$ reduction in $\mathrm{CO}_{2}$ emissions by 2020 (in relation to the situation in 2005) coupled with a further $20 \%$ in 2030 is a considerable challenge for Poland. Based on the analysis, it was found that the largest GHG emissions are associated with the production of energy from hard and brown coal, on which the Polish energy sector is mainly based. Power plants and CHP that use these fuels are more than $90 \%$ responsible for the carbon footprint of this sector. Therefore, achieving this objective will require both new investments, economic and legal instruments related to the replacement of older power plants, improving thermal efficiency and increasing the use of RES. These changes can have significant social, economic and environmental consequences. Therefore, universal tools for assessment and monitoring of environmental impact, which should be based on reliable and well-documented data, are also necessary. Life cycle assessment can be used in order to determine the environmental costs of such initiatives.

A common challenge with life cycle assessment studies is gaining access to publicly available and reliable data (Mallia and Lewis 2013). The specific data collected by public bodies concerned with energy as well as the CSO could be suitable resources for LCA and can contribute to considerably reducing the time and costs of carrying out such analyses. From the perspective of environmental assessment, the LCI as well as the allocation procedure are crucial factors as they constitute a system of complex technological processes and product life cycles connected with such processes. The reliability of any LCA studies conducted in the conditions of an individual country will always be considerably affected by the quality of data relating to electricity, heat generation and distribution.

It was also shown that using an LCA approach for the assessment of energy systems at national level could be a useful tool as it can indicate areas that have a significant impact on the environment (hot spots) taking into account all relevant factors (direct and indirect), which enables a comparison of different alternatives (standardised to $1 \mathrm{TJ}$ ) to be made. Such an approach can encourage technological progress that enables a transition to a long-term sustainable path for the energy system. Therefore, it could be beneficial to implement new environmental assessment tools taking into account the life cycle approach and the juxtaposition of different scenarios. Although the integration of LCA with scenario planning posed certain methodological challenges, it resulted in a calculation of the environmental effect which can be helpful in the planning process and scenario optimisation.

In the present study, we based our results solely on data from the CSO. We would therefore encourage the making of further efforts towards updating the inventory to evaluate the whole life cycle of the Polish energy sector based on specific cradle to grave data (from mining companies, fuel processing plants, power plants, etc.)

Open Access This article is distributed under the terms of the Creative Commons Attribution 4.0 International License (http:// creativecommons.org/licenses/by/4.0/), which permits unrestricted use, distribution, and reproduction in any medium, provided you give appropriate credit to the original author(s) and the source, provide a link to the Creative Commons license, and indicate if changes were made. 


\section{References}

Adamczyk J, Dzikuć M (2014) The analysis of suppositions included in the Polish Energetic Policy using the LCA technique-Poland case study. Renew Sust Energ Rev 39:42-50

Andrae ASG, Andersen O (2010) Life cycle assessments of consumer electronics - are they consistent? Int J Life Cycle Assess 15:827836

Atkins MJ, Morrison AS, Walmsley MRW (2010) Carbon emissions pinch analysis (CEPA) for emissions reduction in the New Zealand electricity sector. Appl Energy 87:982-987

Bieda B (2011) Life cycle inventory of energy production in ArcelorMittal steel power plant Poland S.A. in Krakow, Poland. Int J Life Cycle Assess 16:503-511

Blengini GA, Carlo TD (2010) Energy-saving policies and low-energy residential buildings: an LCA case study to support decision makers in Piedmont (Italy). Int J Life Cycle Assess 15:652-665

Buńczyk A (2013) Eneregtyka cieplna w liczbach - 2012, Urząd Regulacji Energetyki, Warszawa. http://www.ure.gov.pl/pl/rynkienergii/cieplo/energetyka-cieplna-w-1/5377,2012.html. Accessed 29 Oct 2015

Canter K, Kennedy D, Montgomery D, Keats J, Carlyle W (2002) Screening stochastic life cycle assessment inventory models. Int J Life Cycle Assess 7(1):18-26

Cui X, Hong J, Gao M (2012) Environmental impact assessment of three coal-based electricity generation scenarios in China. Energy 45: 952-959

Czaplicka-Kolarz K, Bojarska-Kraus M, Wachowicz J (2004) A life cycle method for assessment of a Colliery's eco-balance. Int J Life Cycle Assess 9:247-253

Dominguez-Ramos A, Held M, Aldaco R, Fischer M, Irabien A (2010) Prospective $\mathrm{CO}_{2}$ emissions from energy supplying systems: photovoltaic systems and conventional grid within Spanish frame conditions. Int J Life Cycle Assess 15(6):557-566

Energy Policy (2009) Energy Policy of Poland until 2030.Appendix to Resolution no. 202/2009 of the Council of Ministers of 10 November 2009 (2009) Polish Ministry of Economy, Warsaw, 2009. http://www.encharter.org/fileadmin/user_upload/Energy policies_and_legislation/Poland_2009_Energy_Policy_to_2030_ ENG.pdf

Environment 2013 (2013) CSO, Regional and Environmental Surveys Department, Warsaw. http://www.pwc.pl/pl_PL/pl/publikacje/ assets/raport rynek ciepla w polsce 2012.pdf. Accessed 20 June 2014

Harrison GP, Maclean EJ, Karamanlis S, Ochoa LF (2010) Life cycle assessment of the transmission network in Great Britain. Energy Policy 38:3622-3631

Hawkins TR, Singh B, Majeau-Bettez G, Strømman AH (2013) Comparative environmental life cycle assessment of conventional and electric vehicles. J Ind Ecol 17:53-64

Henriksson PJG, Zhang W, Guinée JB (2015) Updated unit process data for coal-based energy in China including parameters for overall dispersions. Int J Life Cycle Assess 20:185-195

Hischier R, Baudin I (2010) LCA study of a plasma television device. Int J Life Cycle Assess 15:428-438

Hondo H (2005) Life cycle GHG emission analysis of power generation systems: Japanese case. Energy 30:2042-2056

Informacja w sprawie średnich cen sprzedaży energii elektrycznej wytworzonej w wysokosprawnej kogeneracji oraz na rynku konkurencyjnym za 2007 rok (2008) Prezes Urzędu Regulacji Energetyki. http://www.ure.gov.pl/pl/urzad/informacje-ogolne/ aktualnosci/2593, Informacja-92008-w-sprawie-srednich-censprzedazy-energii-elektrycznej-wytworzon.html. Accessed 29 Oct 2015
Informacja w sprawie średniej ceny sprzedaży energii elektrycznej na rynku konkurencyjnym za rok 2010 (2011) Prezes Urzędu Regulacji Energetyki. http://www.ure.gov.pl/pl/stanowiska/ 3994,Informacja-nr-82011.html. Accessed 29 Oct 2015

Informacja w sprawie średniej ceny sprzedaży energii elektrycznej na rynku konkurencyjnym za rok 2012 (2013) Prezes Urzędu Regulacji Energetyki. http://www.ure.gov.pl/pl/urzad/ informacjeogolne/aktualnosci/5181, Srednia-cena-sprzedazyenergii-elektrycznej-na-rynku-konkurencyjnym-za-rok-2012.html. Accessed 29 Oct 2015

ISO 14040:2009 (2009) Environmental management-life cycle assessment-principles and framework. European Committee for Standardisation. Brussels

ISO 14044:2009 (2009) Environmental management-life cycle assessment-requirements and guidelines. European Committee for Standardisation. Brussels

Jaramillo P, Samaras C, Wakeley H, Meisterling K (2009) Greenhouse gas implications of using coal for transportation: life cycle assessment of coal-to-liquids, plug-in hybrids, and hydrogen pathways. Energy Policy 37:2689-695

Jolliet O, Margni M, Charles R, Humbert S, Payet J, Rebitzer G, Rosenbaum R (2003) IMPACT 2002+: a new life cycle impact assessment methodology. Int J Life Cycle Assess 10:324-330. http://download.springer.com/static/pdf/212/art\%253A10.1007\% 252 F B F 02978505 .pdf? a u th $66=1389341274$ 2d2dd4c3093c9f6b25f6fe6eeb26e099\&ext=.pdf. Accessed 02 January 2014

Kulczycka J, Lelek L (2014) Tools for promoting environmental sustainability in Poland. In: Salomone R, Saija G (eds) Pathways to environmental sustainability - methodologies and experience. Springer, Switzerland, pp 193-203

Kulczycka J, Pietrzyk-Sokulska E (2012) Evaluation of energy sector in Poland. Mineral and Energy Economy Research Institute of the Polish Academy of Sciences, Krakow

Kulczycka J, Kurczewski P, Lewandowska A, Lewicki R, Witczak A, Witczak J (2011) The Polish Centre for Life Cycle Assessmentthe centre for life cycle assessment in Poland. Int J Life Cycle Assess 16(5):442-444

Lean $\mathrm{HH}$, Smyth R (2010) $\mathrm{CO}_{2}$ emissions, electricity consumption and output in ASEAN. Appl Energy 87:1858-1864

Lewandowska A, Foltynowicz Z, Podleśny A (2004) Comparative LCA analysis of industrial objects Part I: LCA data quality assurancesensitivity analysis and pedigree matrix. Int J Life Cycle Assess 9(2):86-89

Lewandowska A, Noskowiak A, Pajchrowski G, Strykowski W, Witczak A (2012) Environmental life cycle assessment of buildings constructed in wood and masonry technology - as an example of LCA application. Wood Technology Institute, Poznan

Lewandowska A, Kurczewski P, Kulczycka J, Joachimiak K, MatuszakFlejszman A, Baumann H, Ciroth A (2013) LCA as an element in environmental management systems - comparison of conditions in selected organisations in Poland, Sweden and Germany Part 1: background and initial assumptions. Int $\mathrm{J}$ Life Cycle Assess 18: $472-480$

Lewandowska A, Noskowiak A, Pajchrowski G, Zarebska J (2015) Between full LCA and energy certification methodology-a comparison of six methodological variants of buildings environmental assessment. Int J Life Cycle Assess 20(1):9-22

Łuba P, Wardak-Bielenis J, Van den Bossche I (2012) Rynek ciepła w Polsce, PwC, Fortum. http://www.pwc.pl/pl_PL/pl/publikacje/ assets/raport_rynek_ciepla_w_polsce_2012.pdf. Accessed 29 Oct 2015

Lucas A, Silva CA, Neto RC (2012) Life cycle analysis of energy supply infrastructure for conventional and electric vehicles. Energy Policy 41:537-547 
Mallia E, Lewis G (2013) Life cycle greenhouse gas emissions of electricity generation in the province of Ontario, Canada. Int $\mathrm{J}$ Life Cycle Assess 18:377-391

Nguyen TLT, Hermansen JE (2012) System expansion for handling coproducts in LCA of sugar cane bio-energy systems: GHG consequences of using molasses for ethanol production. Appl Energy 89: 254-261

Optis M, Wild P (2010) Inadequate documentation in published life cycle energy reports on buildings. Int J Life Cycle Assess 15(7): 644-651

Ou X, Xiaoyu Y, Zhang X (2011) Life-cycle energy consumption and greenhouse gas emissions for electricity generation and supply in China. Appl Energy 88:289-297

Polish Ministry of Economy (2009) Demand for fuels and energy. Projection of demand for fuels and energy until 2030. Appendix 2 to Energy Policy of Poland until 2030. Warsaw. https:// infrastruktura.um.warszawa.pl/sites/infrastruktura.um.warszawa.pl/ files/dokumenty/prognoza_zapotrzebowania_na_paliwa_i_energieost.pdf. Accessed 02 January 2014

Raport 2008 (2008) KSE, Polskie Sieci Energetyczne. http://www.pse.pl/ index.php?dzid $=117 \&$ did $=596$
Raport 2011 (2011) KSE, Polskie Sieci Energetyczne. http://www.pse.pl/ index.php?dzid $=171 \&$ did $=1053$

Raport 2013 (2013) KSE, Polskie Sieci Energetyczne. http://www.pse.pl/ index.php?did=1717

Santoyo-Castelazo E, Gujba H, Azapagic A (2011) Life cycle assessment of electricity generation in Mexico. Energy 36:1488-1499

Tan RBH, Wijaya D, Khoo HH (2010) LCI (life cycle inventory) analysis of fuels and electricity generation in Singapore. Energy 35:4910 4916

The Energy Market Agency (2013) Statystyka Elektroenergetyki Polskiej, Warszawa

Tonini D, Astrup T (2012) LCA of biomass-based energy systems: a case study for Denmark. Appl Energy 99:234-246

Wardenaar T, van Ruijven T, Beltran AM, Vad K, Guinée J, Heijungs R (2012) Differences between LCA for analysis and LCA for policy: a case study on the consequences of allocation choices in bio-energy policies. Int J Life Cycle Assess 17:1059-1067

Yung WKC, Chan HK, Wong DWC, So JHT, Choi ACK, Yue TM (2009) Life cycle assessment of two personal electronic products - a note with respect to the energy-using product directive. Int J Adv Manuf Technol 42:415-419 